\title{
Migrational activity of elements and chemical soil pollution during deposit exploitation in Amur River region and Okhotsk Sea region
}

\author{
Aleksandra Makhinova ${ }^{1}$, Aleksey Makhinov ${ }^{1 *}$ and Viktoriya Kuptsova $^{1}$ \\ ${ }^{1}$ Institute for Water and Environmental Problems, Siberian Branch of the Russian Academy of \\ Sciences, Khabarovsk, Russia
}

\begin{abstract}
We studied mechanisms of geochemical soil systems formation. This work provides geochemical characteristics of soils under the influence of mining enterprises. It also shows the mechanisms of sewage water enrichment by heavy metals during sulphidic deposit exploitation and their interaction with soil substance. We also describe migrational activity of elements and the conditions of their concentration in the soil volume. It is shown that migrational activity of elements depends on both their chemical nature and the level of aggressive fractions of humus acids and background-forming elements ( $\mathrm{Fe}$ and $\mathrm{Mn}$ ) content. The level of heavy metal concentration in soils formed in the area of influence of deposits showed to be exceeded. We suggest new approach to complex evaluation of element reallocation mechanisms in soils. Keywords: migrational activity of elements, migration conditions, element concentration mechanisms.
\end{abstract}

\section{Introduction}

Increased demand on precious metals in the world leads to intense exploration of gold, silver and platinoid deposits. Russia is the third in the world on the known reserves of gold and platinum $[4,15,16]$. More than $60 \%$ of deposits exploited in Russia are located in the Far East. Extraction technology leads to soil devastation $[8,10]$. In the mountain regions near Amur River and Okhotsk Sea the most danger comes from overburden mining, which contributes to chemical pollution of the area. During the evaluation of ecological state of the soil heavy metals become an important point of interest, and all of them are xenobiotics, with lead and cobalt being the most poisonous for human and animals [7].

Large amounts of groundmass are extracted during overburden mining, which leads to multiple increase of the area of their surface of contact to water and oxygen from atmosphere. This problem can be seen not only on overburden grounds, but also in the deforested areas. Sewage water also deals a vast amount of damage to the soil.

The ecological problem of soil devastation and their chemical pollution becomes more and more pressing in deposit exploitation regions $[10,16]$.

"Corresponding author: amakhinov@mail.ru 
Evaluation of migrational activity of elements in the soil volume and the influence of mining industry on the chemical soil pollution is the main objective of this research.

\section{Subject and methods of research}

We have studied natural soils and soils under the influence of ore mining production. Soils within $500 \mathrm{~m}$ from the site of overburden removal have profile deformation (faults and thickening of horizons), they are conventionally called industrial.

The research was conducted from 2000 to 2017 in the following deposit regions: TasYuryakh, Ryabinovyi, Komsomolskaya zalezh, Konder, Mnogovershinnyi.

We analyzed soil samples selected by standard five-spot method in the horizon of 0-30 $\mathrm{cm}$ at 14 sites 10 by $10 \mathrm{~m}$ [23]. All 5 samples from each site were mixed together to form a joint sample.

Physical and chemical properties of the soils were examined using conventional methods [1]; $\mathrm{pH}$ of the soil water suspension was determined by potentiometry using glass electrode. Iron and manganese total form content was determined by acetate method. Total carbon content was determined by dichromatic oxidation method [2]. Total micro-element content was determined on the spectroscope No. 835 (Lif200). Overall, 85 specimen have been analyzed. Most of the samples were analyzed in the certified lab by FGBI Agrochemical Activity Center "Khabarovsky". Part of the samples were re-analyzed in IVEP FEB RAS. Audit samples were examined in the shared analytic center by PGI FEB RAS.

Dynamic models were used to describe material migration processes. For evaluation of probable areas of material migration, geographical interpolation methods were used. Majority of numeric values for elements concentration were processed by conventional statistical methods.

\section{Findings}

The area of research is located in the temperate latitudes of East Asia. It is characterized by humid temperate continental climate with monsoonal features. Annual precipitation ranges between 650 and $800 \mathrm{~mm}$. Areas where deposits are exploited by surface mining have mountain landscape. Sulphide-bearing ores with high levels of $\mathrm{Fe}, \mathrm{Mn}, \mathrm{Cu}, \mathrm{Zn}, \mathrm{Pb}, \mathrm{Ni}, \mathrm{Cd}$ are stocked at the surface in large volumes. Alternate wetting and drying of the loosened rock under violent fluctuations of temperature gradient (within 24 hours, within a year) contribute to sulphide oxidation producing complex cations $\left[\mathrm{FeHSO}_{4}\right]^{+},\left[\mathrm{FeHSO}_{4}\right]^{2+}$, $\left[\mathrm{CuHSO}_{4}\right]^{+}[11,19]$. In case of rapid snow melting and atmospheric precipitation, surface and subsurface flows get formed enriched with fine fractions and heavy metal compounds. These enriched sewage waters contribute greatly to soil pollution.

\subsection{Geochemical characteristics of background soils.}

In the harsh environment near Amur River and Okhotsk Sea topsoil is formed low-contrast. It is characterized by low level of soil variation. The main constituent parts of these background soils are channery brown taiga soils with signs of humic-illuvial leaching. Their position in the landscape defines the quality of organic matter and intensity of humicilluvial process. All variations of soils have these features: a) low thickness of soil profile (up to $40 \mathrm{~cm}$, in the lower parts of the slope up to $70 \mathrm{~cm}$ ); b) low level of finely dispersed grained soil content (4-6\%) [9]; c) weak bacterial decay of forest litter and moss, which 
leads to accumulation of organic matter and formation of humus horizon on the soil surface; d) presence of lasting seasonal frost.

Upper humic-cumulose horizons, 7-12 cm thick, produce humus with high concentration of water soluble violent separates. Structural groups of brown ulminic and fulvic acid, representing 58-88\% of the total composition, react even at temperatures lower than $15^{\circ} \mathrm{C}[14,19]$. Soils have acidic reaction of the environment $\left(\mathrm{pH}_{\mathrm{w}} 3.9-5.8\right)$, their profile is enriched with iron and manganese oxides, and their soluble forms represent 35 $45 \%$ of the total composition. Distribution of oxalate-soluble forms of amorphous iron correlates to the level of fulvic acid structural groups content $[10,13]$.

Geochemical features of soil volume determine physical and chemical state of solid, liquid and biogenic soil phases [6, 12, 20]. Processes of molecular interaction between soil phases and gravity moisture provide conditions for solution and dissolved matter efflux by subsurface flow. Geochemical element activity at the phase boundary in the soil system is defined by the level of iron and manganese content. Environment reaction and humus quality support and control the state of migration flow [21, 22].

Exploitation of ore deposits has influence on geochemical properties of the soils. Increased level of polyvalent metals composition $(\mathrm{Fe}, \mathrm{Cu}, \mathrm{Pb}, \mathrm{Zn})$ in the lower parts of slopes indicates the processes of their migration by subsurface flow.

\subsection{Migrational activity of elements and migration flow.}

Element compounds in soil are defined by their geochemical activity, which is related to the ionic radius and ionic element coordination (table 1) [5].

By the degree of cation geochemical activity and ability to create compounds with humic acids of brown taiga soils they form the following chain: $\mathrm{Fe}^{3+}>\mathrm{Al}^{3+}>\mathrm{Fe}^{2+}>$ $\mathrm{Zn}^{2+}>\mathrm{Cu}^{2+}>\mathrm{Pb}^{2+}>\mathrm{Co}^{2+}$. Relocation of elements in the soil volume by their migrational activity depends on the compound composition, their location in the activity chain, and proportions of different forms of $\mathrm{Fe}^{2-3}, \mathrm{Mn}^{2-5-7}$ in the mineral composition of soils [5]. Migrational activity of cations is defined by the concentration of Fe-Mn, humic substances and soil solution.

Table 1. Geochemical and migrational activity of elements in the hypergenesis area [5]

\begin{tabular}{|c|c|c|c|c|c|}
\hline \multirow[b]{2}{*}{$\begin{array}{l}\text { Ion } \\
\text { coordina } \\
\text { tion }\end{array}$} & \multirow[b]{2}{*}{$\begin{array}{l}\mathrm{A}^{\circ} \\
\text { mean } \\
\text { radius }\end{array}$} & \multirow{2}{*}{$\begin{array}{l}\text { Geochemical } \\
\text { activity of } \\
\text { ions in } \\
\text { minerals }\end{array}$} & \multicolumn{3}{|c|}{ Migrational activity of elements in soils } \\
\hline & & & $\begin{array}{c}3<\mathrm{pH} 5.5 \\
\text { marsh zone }\end{array}$ & $\begin{array}{c}5.5<\mathrm{pH}<6.5 \\
\text { mixing zone }\end{array}$ & $\begin{array}{c}6.5<\mathrm{pH}<7.5 \\
\text { accumulation } \\
\text { zone }\end{array}$ \\
\hline 6 & 0.70 & $\begin{array}{l}\mathrm{Fe}^{2+}, \mathrm{Fe}^{3+} \\
\mathrm{Mn}^{2+}, \mathrm{Ni}, \mathrm{Co} \\
\mathrm{Zn}, \mathrm{Cu}^{2+}, \mathrm{Cd}\end{array}$ & $\begin{array}{l}\mathrm{Fe}^{2+}>\mathrm{Fe}^{3+}>\mathrm{Mn}^{2+} \\
>\mathrm{Cu}>\mathrm{Pb}>\mathrm{Co}>\mathrm{Ni} \\
\mathrm{Cd}>\mathrm{Cr}>\mathrm{Zn}>\mathrm{Sn}^{2+}\end{array}$ & $\begin{array}{l}\mathrm{Fe}^{3+}>\mathrm{Fe}^{2+}>\mathrm{Mn}^{2+} \\
>\mathrm{Cu}>\mathrm{Pb}>\mathrm{Co}>\mathrm{Ni} \\
>\mathrm{Zn}>\mathrm{Sn}^{2+}>\mathrm{Cd}\end{array}$ & $\begin{array}{l}\mathrm{K}>\mathrm{Na}>\mathrm{Fe}^{(2-3)+}> \\
\mathrm{Mn}^{2+}>\mathrm{Pb}>\mathrm{Cu}>\mathrm{Z} \\
\mathrm{n}>\mathrm{Co}>\mathrm{Ni}>\mathrm{Cd}\end{array}$ \\
\hline 8 & 1.00 & $\begin{array}{l}\mathrm{Mn}^{2+}, \mathrm{Cu}^{2+} \\
\mathrm{Zn}^{2+}, \mathrm{Pb}^{2+}\end{array}$ & \multirow{4}{*}{\multicolumn{3}{|c|}{$\begin{array}{l}\text { Elements migrate within soil solutions, organo-mineral } \\
\text { and organo-disperse colloids, balance in the solution } \\
\text { correlates with their degree of litophility and multivalent } \\
\text { cations oxidation in various molecular compounds. }\end{array}$}} \\
\hline $8-12$ & 1.40 & $\begin{array}{l}\mathrm{Cu}, \mathrm{Zn}, \mathrm{As}, \\
\underline{\mathrm{Cd}}, \underline{\mathrm{Sn}}, \underline{\mathrm{Pb}}\end{array}$ & & & \\
\hline \multicolumn{2}{|c|}{ Chalcophilic } & $\begin{array}{c}\mathrm{Fe}, \mathrm{Co}, \mathrm{Ni}, \\
\mathrm{Mn}, \mathrm{P}, \mathrm{Sn}, \mathrm{Cu}\end{array}$ & & & \\
\hline \multicolumn{2}{|c|}{ Siderophilic } & $\begin{array}{l}\mathrm{Zn}, \mathrm{Co}, \mathrm{Fe} \\
\mathrm{Cu}, \mathrm{Pb}, \mathrm{Zn}\end{array}$ & & & \\
\hline
\end{tabular}

Notes: ions in parentheses have transient properties

Migrational activity is the ability of elements to form soluble compounds, an integral quantity indicating the state of migration flow.

Migration flows in soils determine structural groups of soluble humic acids (HA) that bind $\mathrm{Fe}$ and $\mathrm{Mn}$ in heteropolar salts and define chemical properties of polymetals. 
Heteropolar salts are water-soluble. Metals in complex salts can engage in chemical exchange and replacement reactions [20,21].

Background elements (Fe, Mn) and structural groups of humic acids in oxygen-rich soil solutions determine the direction of geochemical processes in soils and formation of migration flows (table 2). Solutions rich in organo-mineral compounds of iron and manganese form buffer zones and contribute to reduction of $\mathrm{Cu}, \mathrm{Zn}$ and $\mathrm{Pb}$ mobility in soil and their settlement [18].

Table 2. Factors determining migrational flows in soils

\begin{tabular}{|c|c|c|c|c|}
\hline $\begin{array}{c}\text { HA } \\
\text { structural } \\
\text { groups }\end{array}$ & $\begin{array}{l}\text { Geochemical } \\
\text { processes in soil }\end{array}$ & $\mathrm{pH}_{\text {wat. }}$ & $\begin{array}{c}\mathrm{Fe} / \mathrm{Mn} \\
\text { solubility }\end{array}$ & $\begin{array}{l}\text { Predominate migrational } \\
\text { flows in soils }\end{array}$ \\
\hline $\mathrm{COOH}$ & Ion exchange & $<4.2$ & $\mathrm{~S} / \mathrm{S}$ & $\begin{array}{l}\mathbf{L} \text { - lateral } \\
\text { (Ls - subsurface, } \\
\text { Lg - overground) }\end{array}$ \\
\hline CAr--OH & $\begin{array}{l}\text { Complex } \\
\text { formation }\end{array}$ & $3.2-4.0$ & $\mathrm{~S} / \mathrm{S}$ & $\begin{array}{l}\mathbf{R}-\text { radial } \\
\text { (Rv }- \text { descending and } \\
\mathrm{Rm} \text { - ascending) }\end{array}$ \\
\hline$>\mathrm{C}=\mathrm{O}$ & $\begin{array}{l}\text { Oxidation- } \\
\text { reduction }\end{array}$ & $>4.5$ & $\mathrm{~S} / \mathrm{P}$ & \multirow{2}{*}{$\begin{array}{l}\text { W - stagnant regime } \\
\text { (Wv - accumulative- } \\
\text { exudational and Wz- } \\
\text { stagnant-cryosolic) }\end{array}$} \\
\hline $\mathrm{C}_{6} \mathrm{H}_{6}$ & $\begin{array}{l}\text { Sorption, } \\
\text { coagulation }\end{array}$ & $>5.5$ & $\mathrm{P} / \mathrm{N}$ & \\
\hline$-\mathrm{CHn}$ & $\begin{array}{l}\text { Hydrophobic } \\
\text { interactions }\end{array}$ & - & $\mathrm{N} / \mathrm{N}$ & $\begin{array}{l}\mathbf{T} \text { - indusrial } \\
\operatorname{Tr}-\text { natural-industrial }\end{array}$ \\
\hline
\end{tabular}

Notes: $\mathrm{S}$ - soluble, $\mathrm{P}$ - poorly soluble, $\mathrm{N}$ - non-soluble

Low $\mathrm{pH}$ values $(<4.5)$ indicate high levels of $\mathrm{H}^{+}$ion concentration in soils.

Consistent patterns of migration flow occurrences and their zones of migration are shown on the map chart of geochemical-landscape zoning of the Amur River basin (see fig.1). New principles and approaches to geochemical-landscape zoning allowed us to reproduce regional background and the connection between migrational flows and conditions of element distribution in the soil volume in the most informative manner.

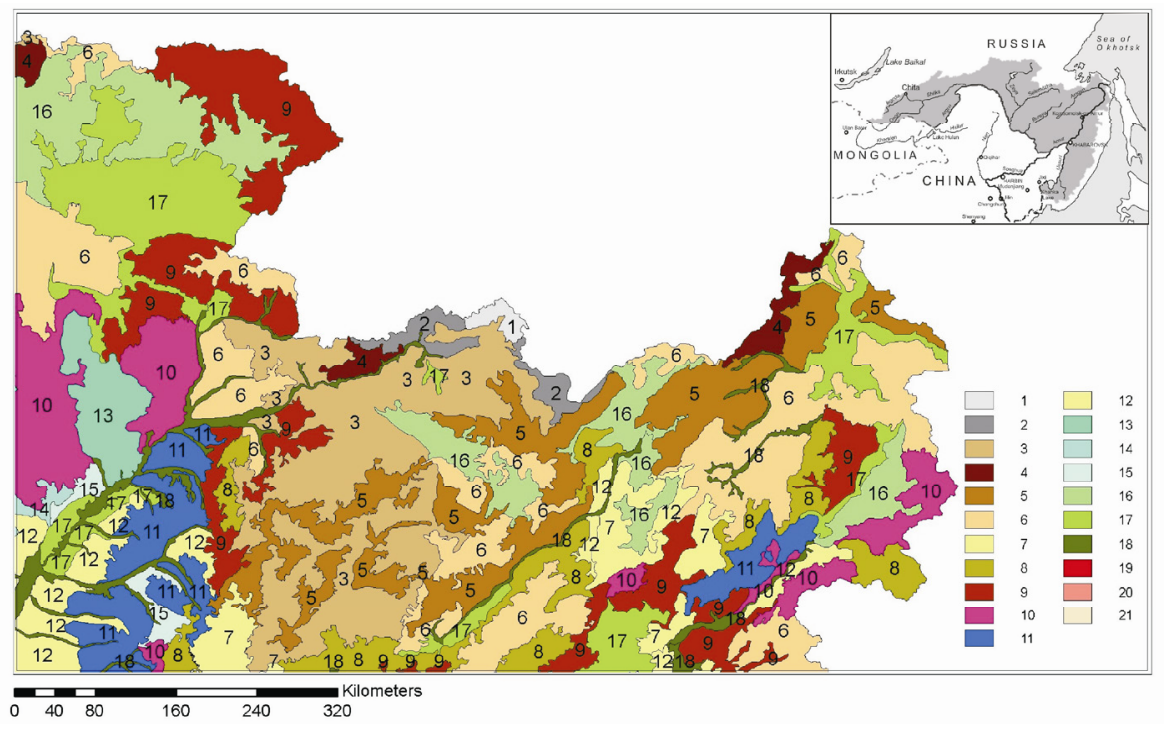

Fig. 1 - Landscape-geochemical zoning of the Amur Basin (fragment of the map)

1. Automorphic cryoturbation zone, 2. Automorphic zone of cryoturbation and mixing, 3. Lateral trans-eluvial zone, 4. Lateral trans-accumulational zone, 5. Lateral-eluvial zone, 6. Lateral-radial zone 
of humatogenesis, 7. Lateral-radial zone of humatofulvogenesis, 8. Radial-lateral for $\mathrm{Fe}^{+3}$, 9. Radiallateral adsorptive zone, 10. Radial-eluvial for $\mathrm{Fe}^{+3}, 11$. Radial zone of intensive trans-accumulation, 12. Radial zone of weak transit, 13. Radial zone of intensive accumulation, 14. Radial zone of exudative accumulation, 15. Radial zone of highly disperse weathering, 16. Zone of radial-aquatic biogenic accumulation, 17. Aquatic zone of inner-accumulation, 18. Super-aquatic trans-eluvial zone, 19. Agrozone, 20. Technozone, 21. Technozone of weathering products.

\subsection{Mechanisms of chemical soil pollution in ore mining production areas.}

We evaluated chemical soil pollution by element concentration values in industrial soils relative to background soils $[6,12,22]$. We looked only at the elements that had concentration values above spectral analysis susceptibility level. Analysis of element concentration in industrial soils indicated their high levels of concentration. Average values are shown in table 3.

With the absence of lateral flow, reallocation of element concentration in soils separated by distance $(\boldsymbol{r})$ is described by the following continuity equation:

$$
D U j(r) \sum_{j}^{n} C j_{r} \leq\left[U_{j}(x+r)-U_{j}(x)\right]^{\wedge} t=\beta W(C j-C)\left(\operatorname{grad} \alpha_{i} C_{j i}\right)_{r} \wedge t,
$$

where $D U_{j}(r) \sum_{j}^{n} C j_{r}$ is element concentration in the specific soil volume; $\beta$ is interphase exchange coefficient; $W$ is volume water content; $C j$ is interphase balance concentration at the point $r$ in the time ${ }^{\wedge} t, C j$ depends on the level of organic compounds and content of fine fractions of silt in horizons. In multicomponent systems the total value of element concentration is connected with their migrational activity gradients $\left(\operatorname{grad} \alpha_{r}\right)$.

Heavy metal distribution in soils presents certain consistent patterns. Element content in background soils does not exceed medium values for the lithosphere. High levels of iron and manganese concentration in the profile are due to the content of soil material and biogenic accumulation $[11,20]$.

Levels of toxic elements $(\mathrm{Cu}, \mathrm{Pb}, \mathrm{Zn}, \mathrm{Mn}, \mathrm{Co})$ content in industrial soils are higher than those in background, reaching maximum concentration in upper organic horizons. This can be clearly seen within $200 \mathrm{~m}$ from the pollution source. In the range of $500 \mathrm{~m}$ down the slope the level of element content decreases slightly.

Migrational activity of $\mathrm{Fe}^{3+}$ and $\mathrm{Mn}^{(4-7)^{+}}$determines behavior of low charge cations $\mathrm{Cu}^{(1-}$ ${ }^{2)+}, \mathrm{Zn}^{2+}$ and $\mathrm{Pb}^{2+}$. For example, specific affinity of $\{\mathrm{Fe}-\mathrm{Mn}$ to copper hydrate ions $\left.\mathrm{Cu}\left(\mathrm{H}_{2} \mathrm{O}\right)_{6}\right]^{2+}$ contributes to coagulation processes that result in formation of copper residue, which is indicated by blue coating on the soil ped surface.

In lateral flow, element migration in the content of geochemical-soil flows with low sorption follows gravity force laws [17]:

$$
\mathrm{F}_{\mathrm{g}}=\mathrm{P}_{\mathrm{b}} \mathrm{gh}=\left[\mathrm{P}_{\mathrm{b}}\left(\mathrm{W}-\mathrm{W}_{\mathbf{m}}\right)\left(\mathrm{W}_{\mathbf{p}}-\mathrm{W}_{\mathbf{m}}\right)_{\mathrm{z}}(\mathrm{g} / \mathrm{L})\right](\sin \alpha)=[\beta \mathrm{Wg} / \mathrm{L}](\sin \alpha)
$$

where $\mathrm{F}_{\mathrm{g}}$ is flow gravity forces; $\mathrm{P}_{\mathrm{b}}$ is soil density; $\mathrm{g}$ is gravity acceleration; $\mathrm{h}$ is wet soil height; $\mathrm{W}$ is mobile moisture volume; $\mathrm{W}_{\mathbf{p}}$ and $\mathrm{W}_{\mathbf{m}}$ are total and maximum soil water capacity; $\beta$ is interphase exchange coefficient; $\mathrm{L}$ is active porosity; $\mathrm{z}$ is coordinate; $\sin \alpha$ is surface slope.

These equations were used to determine cation accumulation levels (table 4).

We evaluated the degree of chemical pollution by concentration accumulation factors (Kc) relative to the average content in the lithosphere (percentage abundance) and the regional background according to the following formula:

$$
\mathrm{Kc}=\mathrm{Ci} / \mathrm{Cb}(\mathrm{r}) \text {, }
$$

where $\mathrm{Ci}$ is level of concentration of the element in the measuring point, $\mathrm{Cb}(\mathrm{r})$ is the background (regional) level of its content for the given soils. Average values of chemical components anomaly levels in soils are shown in table 4.

The total accumulation levels of chemical elements were high on all sites of industrial soils. These data indicate the presence of chemical pollution of topsoil and formation of industrial soils. 

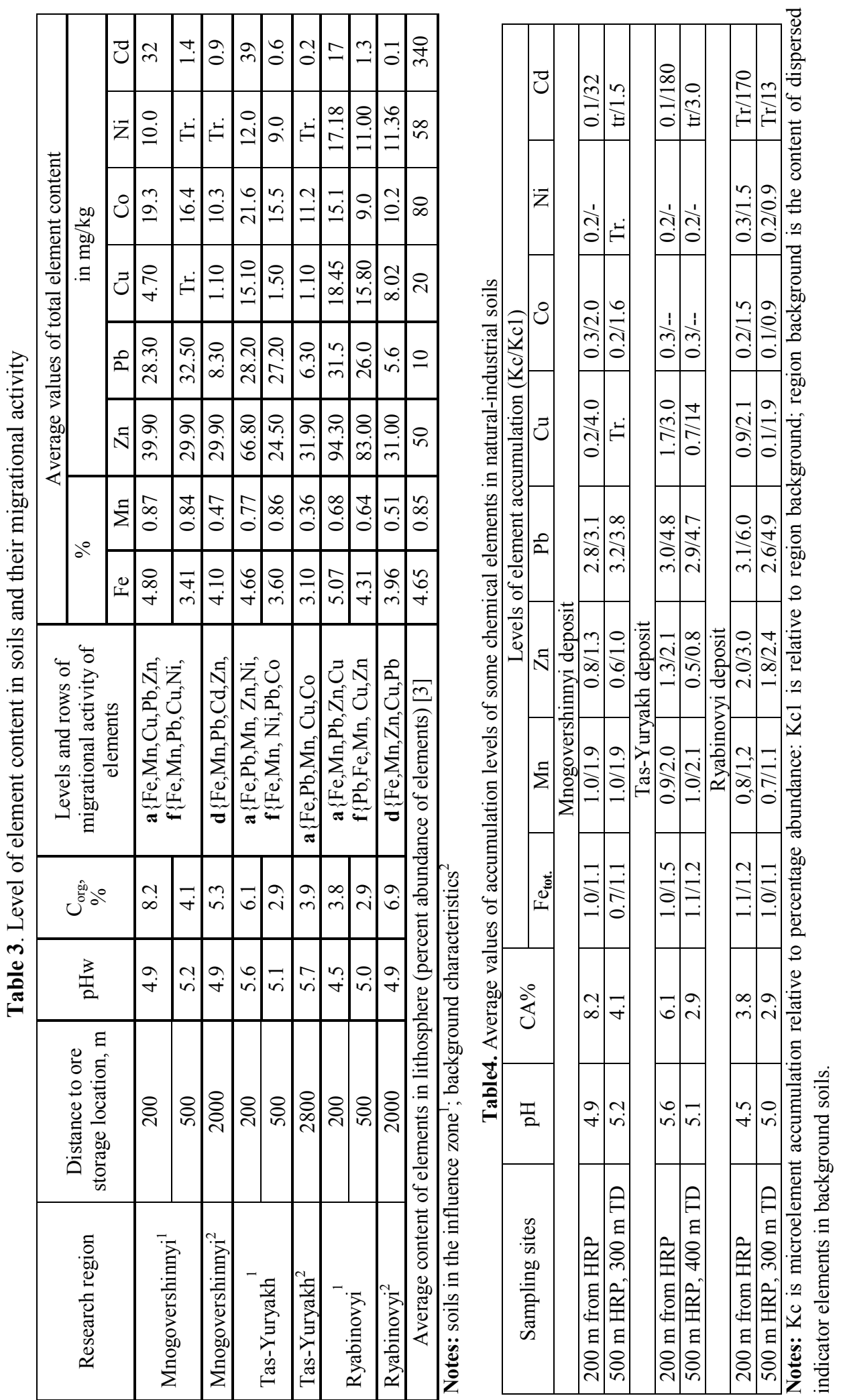


\section{Conclusions}

Distribution of element concentration in the soil volume happens due to flow filtration by descending flow and lateral subsurface flow or by slope wash.

Interaction between sewage waters and soil substance reveals the following: 1) adsorption of fine fractions less than $3 \mu \mathrm{m}$ in size by organic substances; 2) adsorption of dissolved compounds by fine fractions of silt; 3) molecule breaking of complex soils in soil solution; 4) synthesis of organo-mineral complexes in the presence of microorganisms.

Distribution of elements in background and industrial soils has certain consistent patterns: 1) background soils contain predominantly iron-group elements that have high solubility and migrational activity in organo-mineral complexes; 2) polyvalent cations in industrial soils $\left(\mathrm{Fe}^{3+}, \mathrm{Mn}^{(4-7)+}\right)$ get bound by aggressive fractions of organic acids, which contributes to the decrease of $\mathrm{Cu}, \mathrm{Zn}, \mathrm{Pb}$ mobility and their accumulation.

This research was conducted with the financial support of the FEB RAS project No. 09294-2018-0001.

We thank I.V. Perminova, Doctor of Chemistry and professor of the MSU Faculty of Chemistry, for valuable advice in preparing this article.

\section{References}

1. Ye. A. Arinushkina, Chemical soil analysis guidelines (1970).

2. N. P. Belchikova, Agrochemical methods of soil exploration, 56 (1975).

3. A. R. Vinogradov., Geochemistry, 7, 555. (1962).

4. D. V. Voronin, E. A. Gavelya, S. V. Karpov, Ore enrichment, 3, 38 (1994).

5. Yu. Ye. Saet, B. A. Revich, Ye. P. Yanin, Environment geochemistry (1990).

6. M. A. Glazovskaya, Geochemistry of Natural and Technogenic landscapes (2007).

7. V. V. Ivanov, Ecological Geochemistry of Elements (1994).

8. I. A. Kradenykh, Pacific technology, 6:25, 98 (2006).

9. A. F. Makhinova, Topsoil of lower reaches of Amur river region. (1989).

10. A. F. Makhinova, A. N. Makhinov, M. N. Shevtsov, Mountain journal, 4, 83 (2006).

11. A. F. Makhinova, A. N. Makhinov, V. A. Kuptsova, V. V. Yermoshin, J. of Geochem. Exploration, 45 (6). 89, (2013).

12. A. F. Makhinova, A. N. Makhinov, V. A. Kuptsova, Liu Shuguang, V. V. Yermoshin, Pacific geology, 33:2, 76 (2014).

13. D. S. Orlov, N. I. Biryukova, D. S. Sukhanova, Organic composition of the Russian Federation soils (1996).

14. I. V. Perminova, Chemistry and life, 1, 50 (2008).

15. Ye. A. Radkevich, A. I. Khanchuk, Pacific ore belt: materials of new research (2008).

16. B. G. Saksin, Predictive evaluation of regional geochemical influence on natural environment of extracting companies in nonferrous industry in the East of Russia (2012).

17. A. V. Smagin, Soil science, 3, 328 (2003).

18. A. I. Trufanov, Topics of Far Eastern geography, 15, 147 (1975).

19. S. B. Shustov, L. V. Shustova, Chemical basics of ecology (1995).

20. N. B. Uryev, High concentration disperse systems (1980).

21. T. Caprial, H. Beck, P. Harter, Soil Sci.Soc. Amer. J. 54, 415 (1990).

22. N. Senesi, E. Loffredo, Chemical Processes in Soils, 563 (2005).

23. GOST 28168-89. Soils. Sampling. (2008). 